\title{
Ostracod faunas from the Halul, Laffan and Nahr Umr Formations of offshore Abu Dhabi, U.A.E.
}

\author{
JOHN ATHERSUCH
}

BP Research Centre, Chertsey Road, Sunbury-on-Thames, Middlesex TW16 7LN

\begin{abstract}
The Halul and Laffan (Coniacian), and Nahr Umr (Albian) Formations of offshore Abu Dhabi are dated using palynomorphs, foraminifera and nannofossils and their ostracod faunas are illustrated and compared with similar assemblages in the Middle East.
\end{abstract}

\section{INTRODUCTION}

This is the first occasion on which the Cretaceous ostracod faunas of Abu Dhabi have been illustrated, despite their use for many years as biostratigraphic indices in the S. Arabian Gulf area and despite numerous references to them in unpublished oil company reports.

Ostracods with regional stratigraphic value are found at three levels in the Cretaceous of offshore Abu Dhabi (see Fig. 1 for location area). The Halul, Laffan and Nahr Umr Formations each yield distinctive ostracod faunas which compare well with time equivalent assemblages in other parts of the Middle East. The age significance of each of these faunas in Abu Dhabi has been determined by calibration of their occurrences against nannofossil, palynomorph and foraminiferal distributions (see Fig. 2). (a)

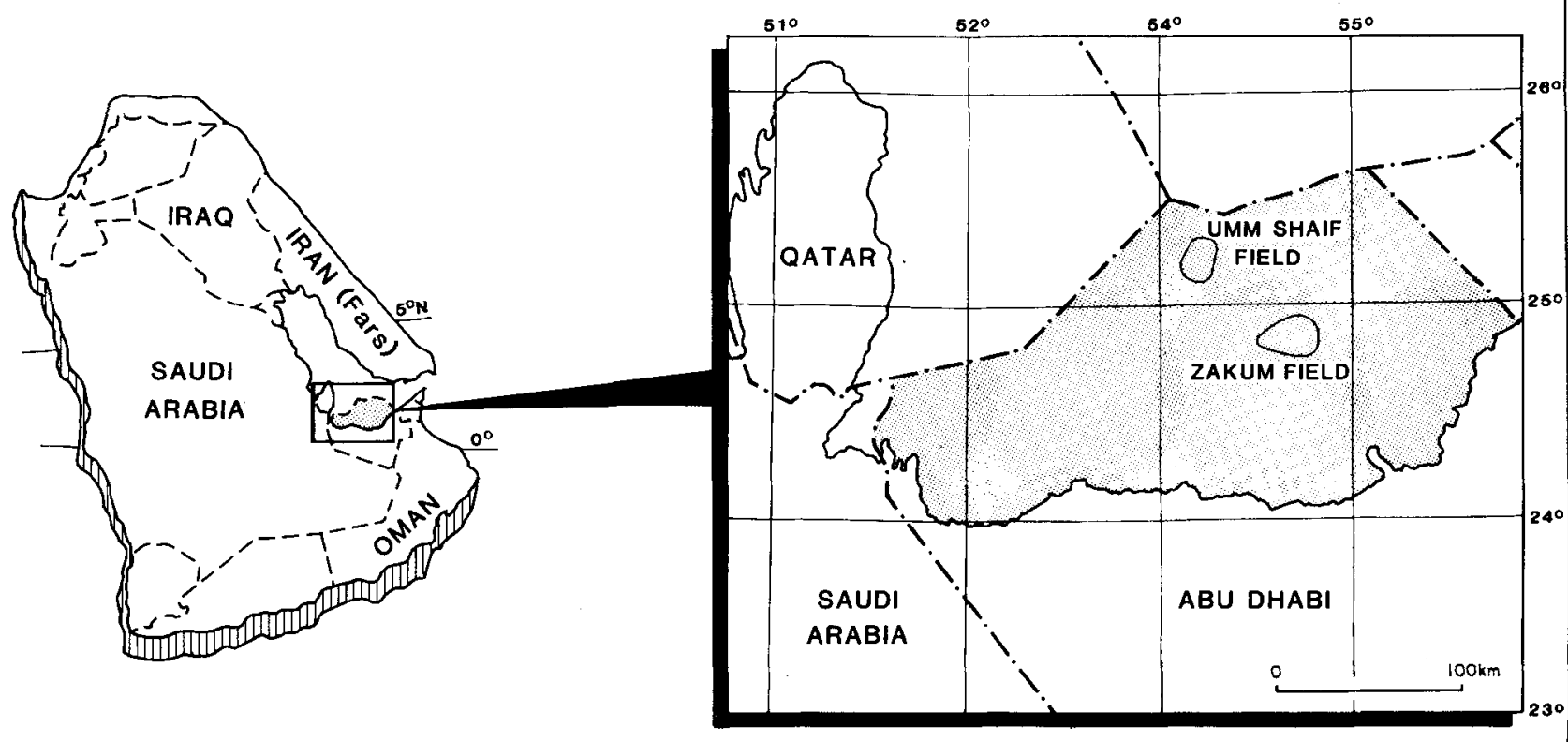

The Study area ( $\bigcirc$ ) at present day.

Fig. 1. The Arabian Plate showing approximate palaeolatitudes for the 'Mid' Cretaceous. 


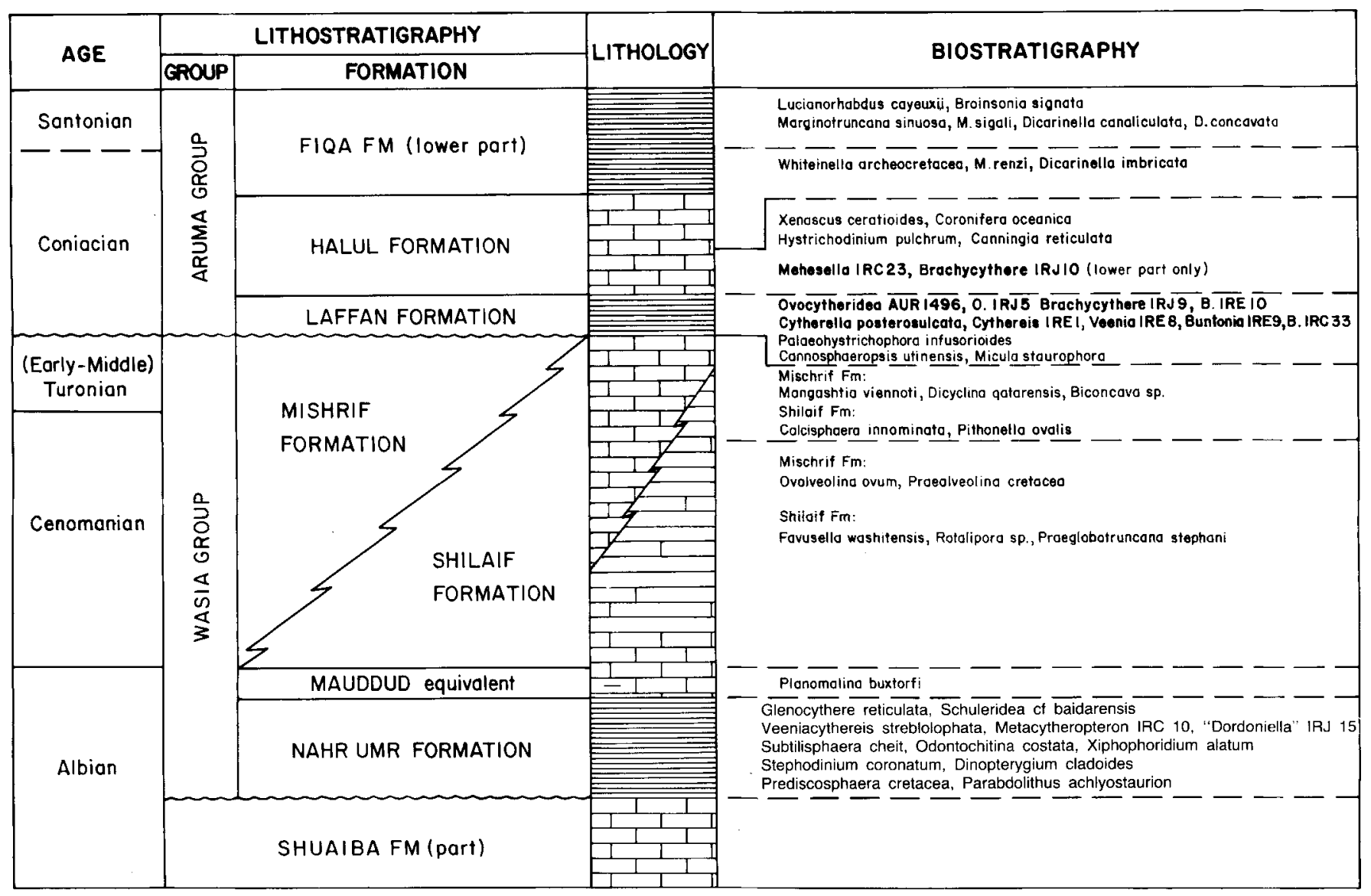

Fig. 2. Stratigraphic distribution of ostracods and key foraminifera, palynomorphs and nannofossils from the Cretaceous succession, offshore Abu Dhabi.

\section{Explanation of Plate 1}

All specimens are $\times 75$

Figs. 1, 2. "Mehesella" cf. IRC23 Grosdidier: fig. 1, right view,; fig. 2, dorsal view. Halul Formation.

Figs. 3-6. "Mehessella" IRC23 Grosdidier: fig. 3, right view of ?male dimorph; fig. 4, dorsal view of ?male dimorph; fig. 5, left view of ?male dimorph; fig. 6, left view of ?female dimorph. Halul Formation.

Figs. 7, 8. Veenia IRD7 Grosdidier: fig. 7, left view; fig. 8, right view. Laffan Formation.

Figs. 9, 10. ?Limburgina IRH31 Grosdidier: fig. 9, right view; fig. 10, dorsal view. Laffan Formation.

Fig. 11. Indet. gen. et sp. ABU1, right view. Laffan Formation.

Fig. 12. Brachycythere IRJ10 Grosdidier, right view. Halul Formation.

Figs. 13-15. Buntonia cf. OMN6 Athersuch: fig. 13, right view of ?male dimorph; fig. 14, right view of ?female dimorph; fig. 15, dorsal view of ?male dimorph. Laffan Formation.

Figs. 16, 17. Brachycythere IRJ9 Grosdidier: fig. 16, right view; fig. 17, dorsal vicw. Laffan Formation.

Figs. 18, 19. Pterygocythere IRD8 Grosdidier: fig. 18, right view; fig. 19, dorsal vicw. Laffan Formation.

Figs. 20, 21. Bairdia cf. IRB35 Grosdidier: fig. 20, right view; fig. 21, dorsal vicw. 


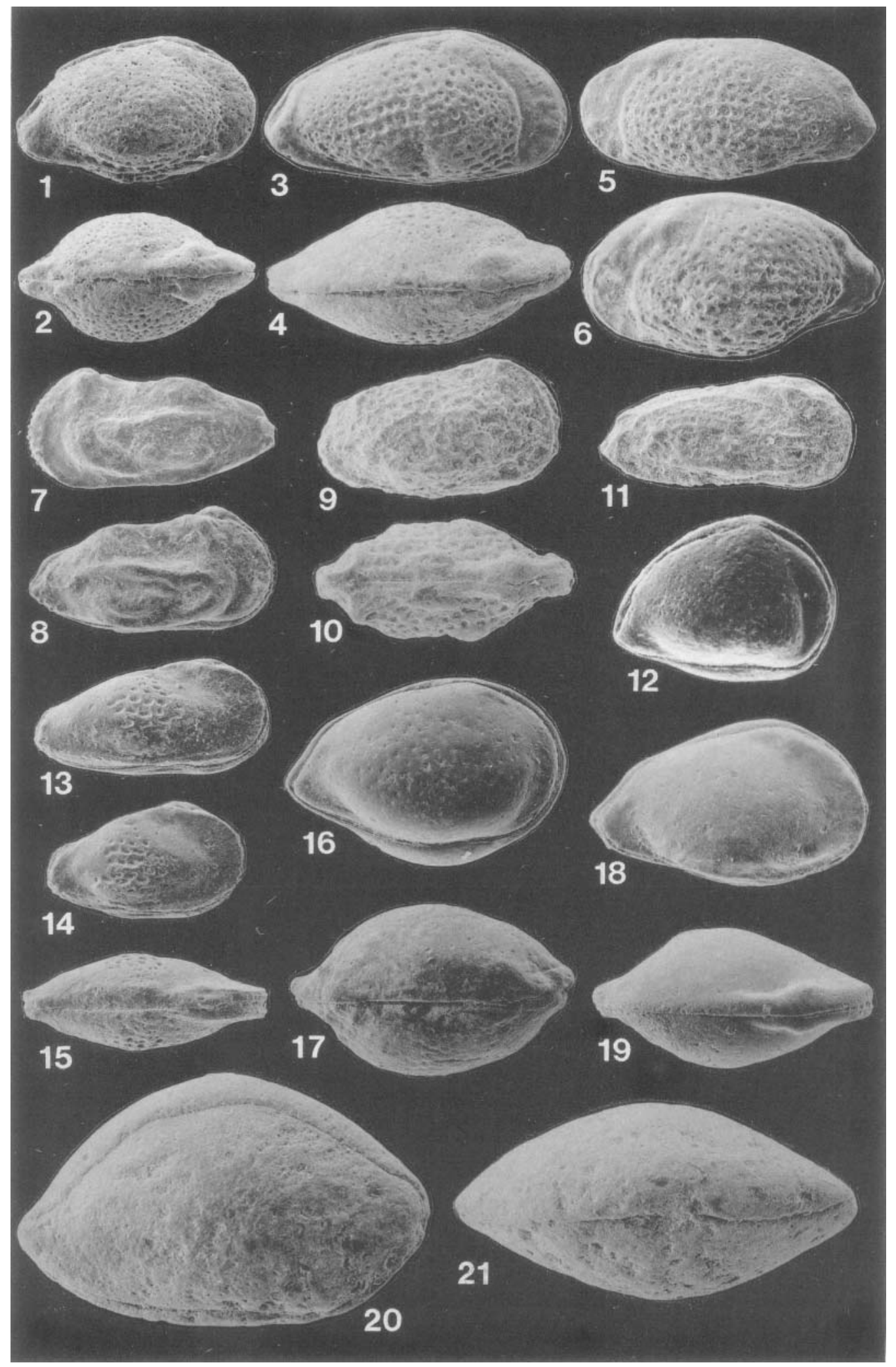




\section{Explanation of Plate 2}

All specimens are $\times 75$

Fig. 1. Indet. gen. et sp. ABU2, right view. Laffan Formation.

Figs. 2, 16. "Echinocythereis" IRJ6 Grosdidier: fig. 2, right view; fig. 16, dorsal view. Laffan Formation. Figs. 3, 13. "Echinocythereis" IRJ6 Grosdidier: fig. 3, right view; fig. 13, left view. Laffan Formation.

Fig. 4. Indet. gen. et sp. ABU3, right view. Laffan Formation.

Fig. 5. Indet. gen. et sp. ABU4, right view. Laffan Formation.

Fig. 6. Indet. gen. et sp. ABU5, right view. Laffan Formation.

Fig. 7. Indet. gen. et sp. ABU6, right view. Laffan Formation.

Fig. 8. Indet. gen. et sp. ABU7, right view. Laffan Formation.

Fig. 9. Indet. gen. et sp. ABU8, right view. Laffan Formation.

Fig. 10. Indet. gen. et sp. ABU9, right view. Laffan Formation.

Fig. 11. Indet. gen. et sp. ABU10, right view. Laffan Formation.

Fig. 12. Dumontina cf. IRE18 Grosdidier, right view. Laffan Formation.

Fig. 14. ?Limburgina IRH31 Grosdidier, left view. Laffan Formation.

Fig. 15. Dumontina cf. IRE18 Grosdidier, right view. Laffan Formation.

Figs. 17-19. Buntonia IRE9 Grosdidier: fig. 17, right view of ?male dimorph; fig. 18, right view of ?female dimorph; fig. 19, dorsal view of ?male dimorph. Laffan Formation.

Fig. 20. Indet. gen. et sp. ABU11, right view. Laffan Formation.

Fig. 21. "Metacytheropteron" IRR24 Grosdidier, left view. Laffan Formation.

Fig. 22. Indet. gen. et sp. ABU12, right view. Laffan Formation.

Fig. 23. Buntonia cf. IRC33 Grosdidier, right view. Laffan Formation.

Fig. 24. ?Hemicytherura sp., right view. Laffan Formation.

Fig. 25. Indet. gen. et sp. ABU13, left view. Laffan Formation.

Fig. 26. Indet. gen. et sp. ABU14, right view. Laffan Formation.

Fig. 27. Indet. gen. et sp. ABU15, right view. Laffan Formation.

Fig. 28. Indet. gen. et sp. ABU16, right view. Laffan Formation.

Fig. 29. Veenia cf. IRD17 Grosdidier, right view. Laffan Formation.

Figs. 30, 31. "Planileberis" cf. IRO16 Grosdidier: fig. 30, right view; fig. 31, dorsal view. Laffan Formation.

Fig. 32. Veenia sp., left view. Laffan Formation.

Figs. 33, 34. Metacytheropteron IRL3 Grosdidier: fig. 33, left view; fig. 34, right view. Laffan Formation.

Figs. 35, 36. Dumontina cf. IRE18 Grosdidier: fig. 35, right view; fig. 36, dorsal view. Laffan Formation.

Figs. 37, 38. Cythereis IRE12 Grosdidier: fig. 37, right view; fig. 38, dorsal view. Laffan Formation.

Figs. 39, 40. Indet. gen. et sp. ABU17: fig. 39, right view; fig. 40, dorsal view. Laffan Formation.

Fig. 41. Indet. gen. et sp. ABU18, right view. Laffan Formation.

Fig. 42. Indet. gen. et sp. ABU19, right view. Laffan Formation.

Fig. 43. Indet. gen. et sp. ABU20, right view. Laffan Formation.

Fig. 44. Indet. gen. et sp. ABU21, right view. Laffan Formation.

Figs. 45, 46. Indet. gen. et sp. ABU22, left views (of two dimorphs?). Laffan Formation.

Figs. 47, 48. Veenia IRE8 Grosdidier: fig. 47, right view; fig. 48, dorsal view. Laffan Formation. 
Ostracods from the Cretaceous of Abu Dhabi, U.A.E.

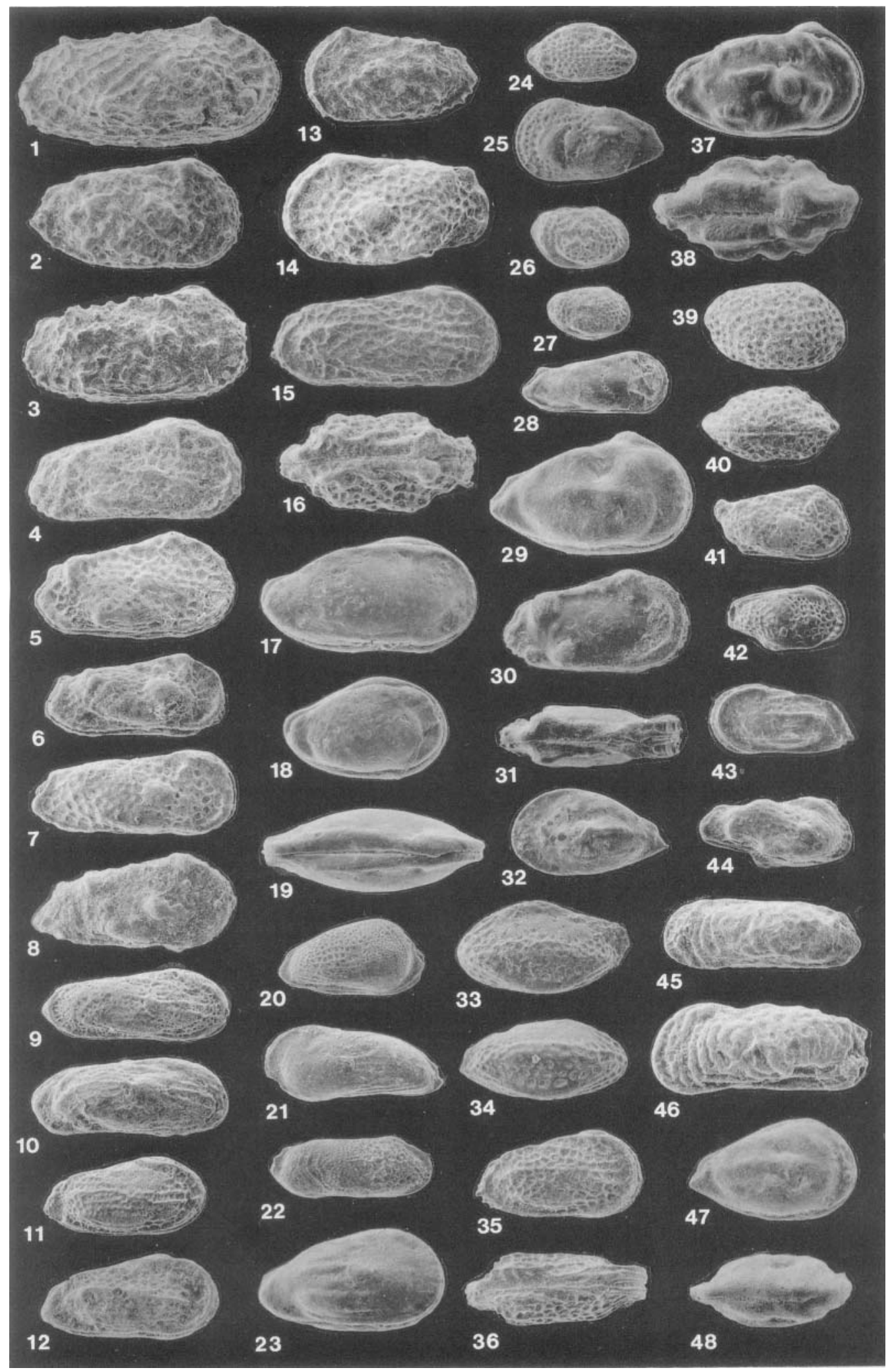


The faunas of the Halul and Laffan Formations illustrated herein are best compared with those described by Grosdidier (1973) from Iran. The Nahr Umr faunas are more widely distributed along the midCretaceous southern Tethyan shelf and are known from many N. African, Levantine and Middle Eastern localities. The distribution of these faunas is reviewed by Athersuch (1985, in press).

Plates 1-4 depict most of the ostracods recovered from the three formations in offshore Abu Dhabi. None of the species have been formally described, and previously undescribed species (prefixed ABU) have been left in open nomenclature as, due to the proprietary nature of the material, the exact provenance of individual specimens cannot be revealed. For the Halul and Laffan Formations, most specimens were recovered from core samples, a few from ditch cuttings. The Nahr Umr material comprised ditch cuttings alone.

\section{THE OSTRACOD FAUNAS}

\section{The Halul Formation}

The Halul Formation has been dated as Coniacian in age throughout the region on the basis of the planktonic foraminifera Whiteinella archaeocretacea, Marginotruncana renzi and Dicarinella imbricata and the dinoflagellate cysts Xenascus ceratioides, Coronifera oceanica, Hystrichosphaera pulchrum and Canningia reticula$\mathrm{ta}$. The lower part of this formation, which is developed in a marine 'reefal' lime-mud facies, is characterised by the ostracoda Brachycythere spp. (including $B$. IRJ10 Grosdidier) and "Mehesella" spp. (including ' $M$ '. IRC23 Grosdidier). The former species has a Coniacian age range in Iran, but ' $M$ ' sp. IRC23 is apparently restricted to the Santonian there (Grosdidier, 1973).

\section{The Laffan Formation}

The Laffan Formation is dated as Coniacian by the occurrence of the dinoflagellate cyst Cannosphaeropsis utinensis and by the nannofossil Micula staurophora. Shallow marine shales within the formation yielded large and diverse assemblages of ostracods. Over 30 species were recorded in the offshore Abu Dhabi area. Many of these are previously undescribed forms, but some are known from the Coniacian Laffan Formation of Iran (Grosdidier, 1973). The principal indices of this formation are Cythereis IRE12 Grosdidier, Brachycythere spp. (B. IRJ9, B. IRE10 Grosidier), Ovocytheridea AUR1496 Grekoff, Buntonia spp. ( $B$. IRE9, $B$. IRC33 Grosdidier) and Veenia IRE8 Grosdidier. Other previously recorded species found in this formation are Veenia IRD17 Grosdidier, ?Limburgina IRH31 Grosdidier, ?Dumontina cf. IRE18 Grosdidier, Metacytheropteron IRC3 Grosdidier, $M$. IRR24 Grosdidier, 'Planileberis' cf. IRO16 Grosdidier, Ovocytheridea IRJ5 Grosdidier and Cophinia cf. IRD12 Grosdidier. All of these species have been recorded from the Coniacian Laffan Formation in Iran by Grosdidier. In addition, Cytherella posterosulcata Al-Abdul-Razzaq, previously recorded from the Santonian and Coniacian throughout the Middle East (Athersuch, 1985) was also recovered.

There are insufficient data to determine precisely the palaeoenvironmental significance of most of the species recovered from the Laffan Formation. However, it is presumed that the great variation in faunas from one locality to another observed in the offshore Abu Dhabi area reflects facies control. In this respect it is

\section{Explanation of Plate 3 \\ All specimens are $\times 75$}

Fig. 1. Paracypris sp., right view. Laffan Formation.

Figs. 2-4. Cytherella sp.: fig. 2, left view; fig. 3, right view; fig. 4, dorsal view. Laffan Formation.

Figs. 5-7. Cytherella posterosulcata Razzaq: fig. 5, right view; fig. 6, left view; fig. 7, dorsal view. Laffan Formation. Figs. 8, 9. ?Cophinia IRD12 Grosdidier: fig. 8, right view; fig. 9, dorsal view. Laffan Formation.

Fig. 10. Indet. gen. et sp. ABU23, right view. Laffan Formation.

Fig. 11. Cytherella sp., left view. Laffan Formation.

Fig. 12. ?Pontocyprella sp., left view. Laffan Formation.

Fig. 13. ?Macrocypris sp., left view. Laffan Formation.

Figs. 14, 15. ?Cophinia cf. IRD12 Grosdidier: fig. 14, right view; fig. 15, dorsal view. Laffan Formation.

Figs. 16, 17. Ovocytheridea AUR1469 Grekoff: fig. 16, right view; fig. 17, dorsal view. Laffan Formation.

Figs. 18, 19. Ovocytheridea IRJ5 Grosdidier: fig. 18, right view; fig. 19, dorsal view. Laffan Formation.

Fig. 20. Pontocyprella sp., right view. Laffan Formation. 
Ostracods from the Cretaceous of Abu Dhabi, U.A.E.

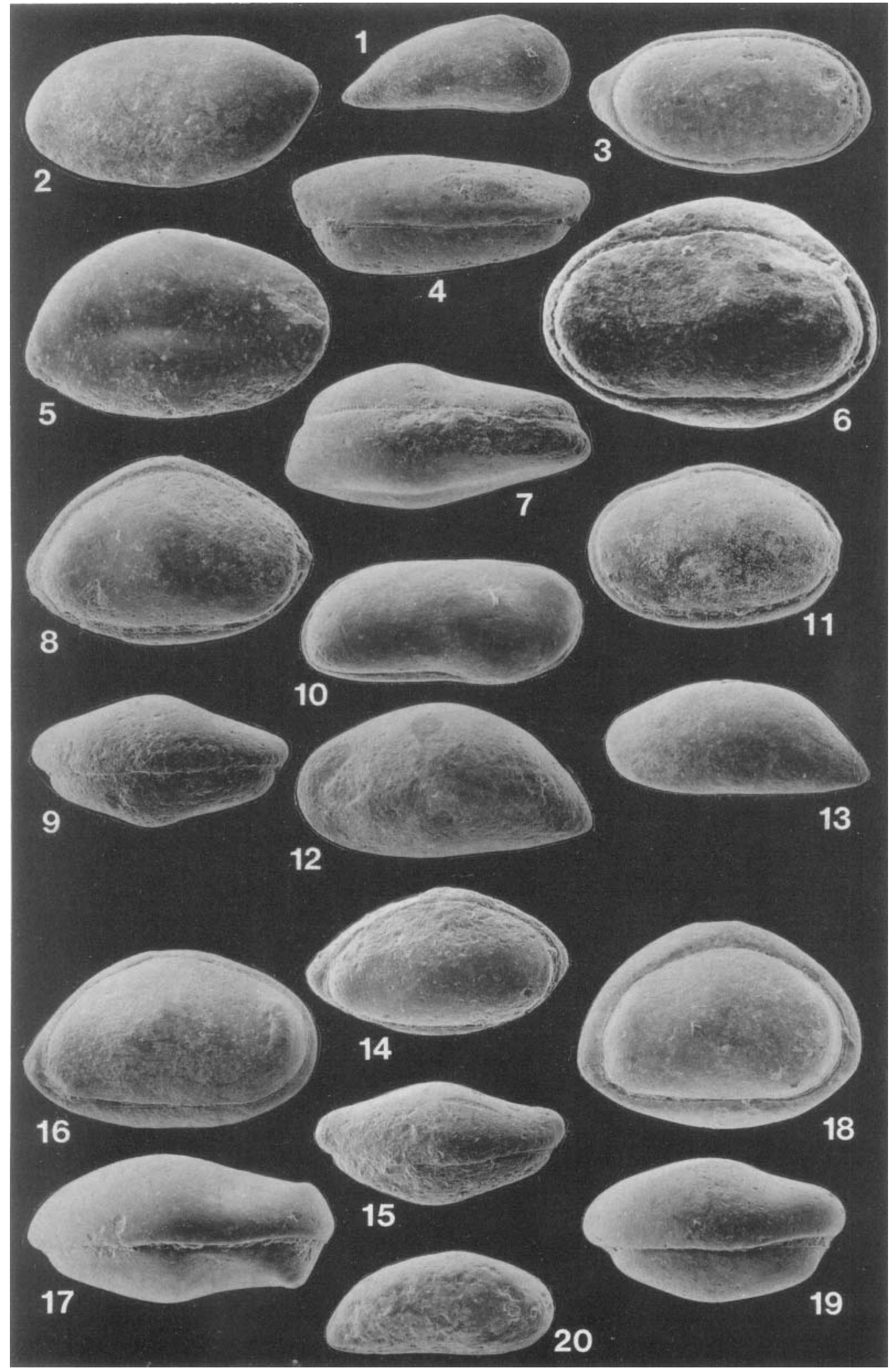


interesting to note that most of the 'indeterminate' taxa recorded herein are from the flanks of a basin which existed in the offshore area during Laffan times. This suggests that endemic faunas developed in marginal marine areas at this time. In basinal areas, taxa with regional affinities were more frequently recovered.

\section{Nahr Umr Formation}

The transgressive marine shales of the Nahr Umr are dated as Albian in the offshore Abu Dhabi area on the basis of the nannofossils Prediscosphaera cretacea, Parhabdolithus achlyostaurion and the palynomorphs Subtilisphaera cheit, Xiphophoridium alatum, Dinopterygium cladoides. The occurrence of the planktonic foraminifer Planomalina buxtorfi (latest Albian) in the overlying Mauddud equivalent also supports an age no younger than Albian for this formation. This age assignment is consistent with the age previously determined for this formation in other parts of the Middle East.

Characteristic ostracod species for this formation are Glenocythere reticulata Razzaq, Veeniacythereis streblolophata Razzaq, Schuleridea cf. baidarensis (Damotte \& St. Marc), Schuleridea IRJ15 (Grosdidier) and Metacytheropteron IRC10 Grosdidier. Of these species, $S$. baidarensis and $M$. IRC10 are known only from Albian sediments in the Middle East, $V$. streblolophata has previously been recorded only from the Early
Cenomanian and $G$. reticulata has a documented Albian to Early Cenomanian age range (Athersuch, 1985).

\section{ACKNOWLEDGEMENTS}

I would like to thank the Ministry of Petroleum, Abu Dhabi and the management of ADMA-OPCO, Abu Dhabi for permission to publish this paper. I acknowledge with gratitude the British Petroleum Co. p.l.c. for providing financial and logistical support.

Manuscript received July 1985

Revised manuscript accepted September 1985

\section{Explanation of Plate 4}

All specimens are $\times 75$

Figs. 1, 2, 6, 7. Brachycythere IRJ9 Grosdidier: figs. 1, 2, right views of ?male dimorphs; fig. 6, dorsal view of ?female dimorph; fig. 7, right view of ?female dimorph. Laffan Formation.

Figs. 3-5. Brachycythere IRE10 Grosdidier: fig. 3, right view of ?female dimorph; fig. 4, right view of ?male dimorph; fig. 5, dorsal view of ?female dimorph. Laffan Formation.

Fig. 8. Brachycythere cf. IRJ9 Grosdidier, right view. Laffan Formation.

Fig. 9. Brachycythere sp., right view. Laffan Formation.

Fig. 10. Schuleridea cf. baidarensis (Damotte \& St. Marc), left view. Nahr Umr Formation.

Fig. 11. Indet. gen. et sp. ABU24, left view. Nahr Umr Formation.

Fig. 12. ?Schuleridea sp., right view. Nahr Umr Formation.

Fig. 13. Metacytheropteron IRC10 Grosdidier, left view. Nahr Umr Formation.

Fig. 14. Indet. gen. et sp. ABU25, right view. Nahr Umr Formation.

Fig. 15. Glenocythere reticulata Razzaq, left view. Nahr Umr Formation.

Figs. 16, 17. Cytherella cf. IRC6 Grosdidier: fig. 16, right view; fig. 17, dorsal view. Nahr Umr Formation.

Fig. 18. Cythereis sp., right view. Nahr Umr Formation.

Fig. 19. Veeniacythereis streblolophata Razzaq \& Grosdidier, left view. Nahr Umr Formation.

Fig. 20. Cythereis IRE12 Grosdidier, left view. Laffan Formation. 


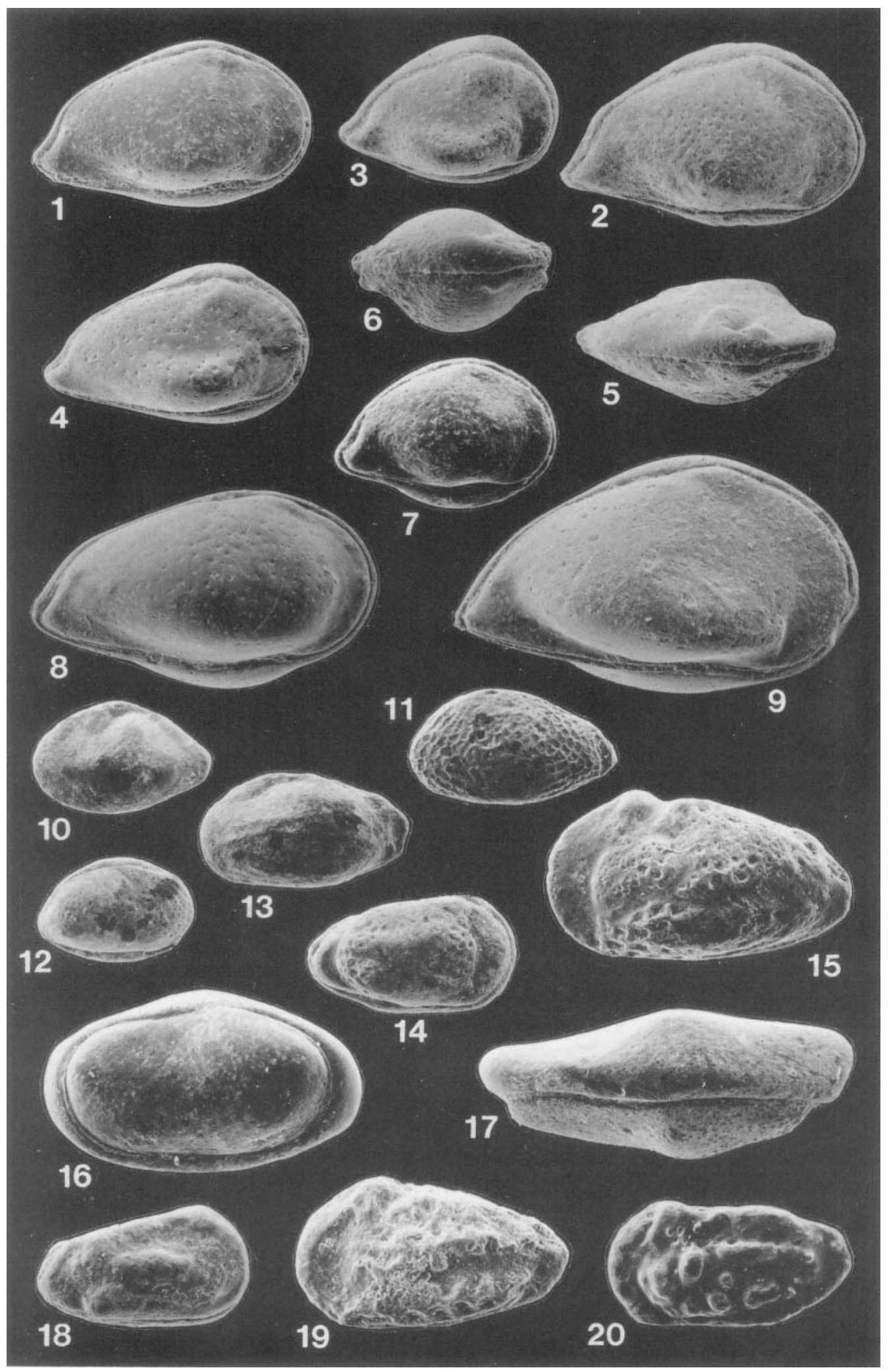




\section{REFERENCES}

Al-Abdul-Razzaq, S. K. 1979. Glenocythere, a new ostracode genus from the Ahmadi Formation (Cretaceous) of Kuwait. J. Paleont. Tulsa, 53 (4), 920-930.

Al-Abdul-Razzaq \& Grosdidier, E. 1981. Ostracode index species from the Cenomanian of the South shelf of the Tethys Sea. Bull. Centres Rech. Explor.-Prod. ElfAquitaine, Pau, 5 (2), 173-191.

Athersuch, J. 1985 (in press). The biostratigraphy of Cretaceous Ostracods from Oman. (Proc. 9th Int. Ostracod Symp., Shizuoka, 1985).

Damotte, R. \& Saint-Marc, P. 1972. Contribution a la connaisance des Ostracodes Cretaces du Liban. Rev. Micropaleont. 4 (3). 273-296.

Grekoff, N. 1962. Sur le genre d'Ostracodes Ovocytheridea Grekoff (1951). Rev. Micropaleont., 5 (2), 115-122.

Grosdidier, E. 1973. Association d'ostracodes du Cretace d'Iran. Rev. Inst. Fr. Petrol., 28 (2), 131-169. 